Globalizations

\title{
Constructing world society: international organizations, otherhood and the rise of global reporting
}

\section{Mike Zapp}

To cite this article: Mike Zapp (2020): Constructing world society: international organizations, otherhood and the rise of global reporting, Globalizations

To link to this article: https://doi.org/10.1080/14747731.2020.1764691

$$
\text { Published online: } 19 \text { May } 2020 .
$$

Submit your article to this journal

Q View related articles $₫$

View Crossmark data $₫$ 


\title{
Constructing world society: international organizations, otherhood and the rise of global reporting
}

\author{
Mike Zapp \\ Department of Social Sciences, Université du Luxembourg, Luxembourg, Luxembourg
}

\begin{abstract}
Global reporting by international organizations (IOs) has become a widespread phenomenon in a range of policy sectors. This article analyses an original dataset of $N=110$ explicitly global reports from the period 1947-2019. Results show a striking increase in reports since the 1990s for all sectors and types of reports. In particular, reports addressing social entities (e.g. the world's children) and issues such as human development are most prevalent. Further within-report analyses show that more recent reports now routinely aggregate to the world level. I argue that this aggregation is indicative of intensified (yet not unthreatened) efforts to construct an 'imagined world society' through IOs' otherhood, i.e. their agency for other actors, principles, and entities.
\end{abstract}

\section{KEYWORDS}

Global reporting; international organizations; otherhood; agency; world society

\section{Introduction}

World society has been described as a stateless institutional order that rests upon shared principles, rules and models (Drori et al., 2003; Meyer et al., 1997). Lacking centralized power, the construction of and integration into such a world society occurs mainly through 'otherhood'. Otherhood refers to the social process of enacting agency for other actors (e.g. nation-states), principles (e.g. human rights) and non-actor entities (e.g. the world's children; endangered species) (Meyer, 2019; Meyer \& Jepperson, 2000). International organizations, both intergovernmental and non-governmental (IGOs \& INGOs), are prime examples of 'others' which exert otherhood as they provide the core elements of world society. They perform agency for the key principles of social organization and integrate into such world society by representing those entities that cannot themselves engage in direct agency.

This paper argues that othering activities have intensified in the more recent period reflected in the striking increase of global reports. IOs publish global reports as key or 'flagship' publications which are costly and require careful preparation. They consist of a formal, standardized and often scientific account of phenomena deemed by their international authors to be of global scope, relevance and occurrence. They represent a systematic expression of universal, i.e. human or planetary, concerns. By way of example, global reports analyse a wide range of issues such as the state of biodiversity (e.g. the Food and Agriculture Organization's Report on The State of the World's Plants); the situation of children (e.g. United National Children Fund's The State of the World's Children); the status of human health (e.g. the World Health Organization's Report on the Global Aids 
Epidemic); and threats to academic freedom worldwide (e.g. Scholars at Risk's Academic Freedom Global Monitoring Report). These issues reflect some of the core areas of world society (see contributions in Krücken \& Drori, 2009). This present study analyses these global reports as sector-specific accounts of those universal principles and entities which are recognized as part of world society, and which require particular attention and action by that world society.

The article presents original data on $N=110$ reports that explicitly deal with issue areas deemed global. Analyses focus on three main aspects. The study, first, analyzes the rise and spread of global reports with regard to policy sectors or world society domains. It, second, identifies the reported types of agency and related principles and entities. Finally, this study examines specific reporting practices, namely the levels of aggregation in the use of statistical indicators over time.

Results show a slow increase in the number of reports in the post-World War II period and a striking growth in reports since the 1990s. Virtually all sectors are now understood as being of global relevance including disaster relief and internet access, health and well-being, education and work. Some issue areas are covered by multiple reports, notably human development and empowerment as well as environment, biodiversity and animal rights.

More detailed analyses of principles and entities addressed by reports identify human rights and economic empowerment as key principles. With the rise of entity-related reports, references to natural entities - particularly resources, and environmental phenomena - as well as social groups - particularly children, women and people with special needs - have begun to increase considerably since the mid-1990s. The rise of non-social and social focus reports supports arguments for, first, the rationalization of the world as a 'world risk society' (Beck, 2009) that requires scientific analysis and systematic intervention and, second, the 'triumph of the individual' (Elliott, 2007; Meyer \& Jepperson, 2000) in world society reflected in calls for empowerment of all persons and particularly those social groups perceived as disadvantaged.

Finally, further within-report analyses document a significant shift in reporting practices. While the nation-state remains an important unit in the analysis of global issues, more recent reports now routinely dis-embed from the national context aggregating indicators to regional and world levels. This shift suggests an important ontological change. With data cross-nationally standardized and goals globally chartered, world society has become a statistical reality (Hwang, 2006). By measuring the world as an aggregated whole, global reports reflect an unprecedented level of global awareness of interdependence and one-ness and evoke an 'imagined world community', reminiscent of nationbuilding processes in a previous era (Anderson, 1991). Provided that current waves of illiberal and anti-globalization ideologies do not undermine such dynamism (Schofer et al., 2018), world society expansion, both structurally and culturally, is likely to remain strong.

\section{Otherhood and the construction of world society by international organizations}

World society has been described as an expansive and decentralized institutional order involving multiple actors at multiple levels (Drori et al., 2003; Meyer et al., 1997). Issue areas, policy domains or governance sectors - the substance of world society - have expanded considerably and are reflected in an equally expansive number of organizational actors. Among these, intergovernmental organizations (IGOs), civil society organizations, social movements, international non-governmental organizations (INGOs), universities and research institutes now routinely engage in world society discourse. Indeed, the number of IGOs has risen from only 37 in the early twentieth century to 7,710 one hundred years later. Similarly, INGOs, well below 200 organizations before World War I, now span the globe in a vast associational network of more than 60,000 organizations (Boli \& 
Thomas, 1999; UIA, 2017). They cover a plethora of human concerns including everything from environmental protection to sexual and reproductive health and child labour. Such dynamism is defined by crucial moments in history that mary, contract or increase the expansion and thematic scope of world society. World Wars I and II are typically identified as contractive phases, while their aftermath (together with the fall of the Berlin Wall) are considered catalysts of world society expansion (Schofer et al., 2018).

World society is also a stateless and decentralized order and does not replicate national structures at the global level; instead 'almost all the interests that push for sociopolitical regulation in the world work toward building a broad world polity of shared rules and models, rather than trying to assemble a stronger world state bureaucracy' (Meyer 2000, p. 239). Such statelessness has important consequences for understanding the construction of and integration into world society.

Lacking traditional mechanisms of control and authority, world society is constructed through 'otherhood'. 'Othering' or 'otherhood', here, refer to the social process of enacting agency for other actors, principles and non-actor entities (Meyer, 2019; see below). Related, lacking a clear and designated centre of power, conventional actors (nation-states) share such otherhood with non-state actors, often conceived of as 'global governance' in international relations (Barnett \& Finnemore, 2004). In such a multi-actor system, international organizations (IOs), both intergovernmental and non-governmental, are of particular importance and will be given detailed attention.

Traditionally, IOs were seen as either tools of powerful nation-states or rational solutions to reduce transaction costs and coordination problems in increasingly complex international sectors such as security and trade (see Zapp, 2017b for a review). More recent accounts stress however, the role of IOs as global knowledge providers, central nodes for the diffusion of norms, agents of reflexive modernization and creators of global public spheres (Barnett \& Finnemore, 2004; Beck, 2009; Chabbott, 2003; Frank et al., 2000; Lerch, 2019). Supported by personnel that are highly specialized in the management of global problems, they accumulate massive data and policy knowledge and couple such cognitive capacity with a clear mission; thereby lending these actors additional legitimacy. This mission consists in IOs' defense of the 'good' and 'noble', they reveal the 'risks' of modernity and, as mentioned above, routinely raise the voice for those groups and issues they consider particularly important and vulnerable (see for reviews Beck et al., 2003; Elliott, 2007; Lechner \& Boli, 2014; Union of International Organizations [UIA], 2017 as well as contributions in Littoz-Monnet, 2017). Through this novel perspective, IOs can be seen as 'rationalized others' - a reference to G. H. Mead's (1962) 'generalized others' - as they provide standardized and often scientized (hence the 'rationalized') blueprints for appropriate behavior in world society, often supported by strong sector-specific expertise (Meyer et al., 1997, p. 165; Meyer et al., 1987; Petiteville, 2018).

As opposed to usages in philosophy and social psychology, in an institutionalist line of explanation, othering or otherhood represent a specific form of relational agency, i.e. agency for others. I elaborate on the various types of otherhood related to international organizations.

The first type, agency for other actors, describes the shift from 'actorhood' to 'otherhood' (Meyer, 1996; Meyer \& Jepperson, 2000). IOs routinely engage in agency for other actors, notably states, by prescribing reform templates. They respond to and drive policymakers' quest for evidence-based policymaking, and act as producers and transmitters of policy-relevant knowledge in general. It is important to note that although founded and funded by states, even intergovernmental organizations possess legitimacy above and beyond state support and often act overtly against their governmental patrons (Barnett \& Finnemore, 2004). This does not imply that national sovereignty or supranational subsidiarity lose relevance vis-à-vis IOs' authority. Instead, it shall be noted that the relationship between IOs and nation-states is complicated by the fact that IOs are often called upon precisely 
because they seem equipped with expertise and invested in disinterested policy recommendations (Tallberg \& Zürn, 2019).

Second, IOs assume responsibility to act as agents of particular principles, i.e. natural and moral laws and values. These instances of cultural authority include, most prominently, the key ideals of world society - justice and freedom. It has long been noted in comparative sociology and international relations that agency for principle has always been the mandate for many IOs, with human rights being a prominent example since the establishment of multilateralism through the United Nations after WW II (e.g. Cole, 2016; Finnemore \& Sikkink, 1998; Ruggie, 1998).

A third type of agency refers to agency for the concerns of recognized non-actor entities. These entities represent non-social, physical or natural non-actors like dying languages, the ecosystem and climate, or animal species. They are described as non-actors as they do not have the capabilities to act vis-à-vis other agentic entities (e.g. states). IOs are increasingly associated with advocacy for these non-social entities. Hironaka (2002), for instance, stresses the role of IOs in raising awareness for environmental protection. Similarly,Shandra (2007) identifies the crucial role of IOs in decreasing deforestation. In general, Zapp (2017a) finds that environmental, habitat and biodiversity issues are some of the most active areas of both IGOs' and INGOs' research activities.

Another form of non-actor entity is of a social nature. These entities include, for example, the world's children, women or indigenous cultures. These entities also lack proper agentic status when considering individual action and are given external representation only as collective actors. Counterintuitive as it may seem, yet such aggregated social non-actor groups usually enter policy discourses via formal organizations and even social movements committed to fight climate change, female mutilation and landmines quickly formalize their status by setting up an office, electing a governing report and publishing activity reports (Boli \& Thomas, 1999; Bromley \& Meyer, 2015).

Moreover, recent research stresses that IOs' broad advocacy of human rights (as principle) has shifted toward more concrete advocacy for particular social groups. Analyzing all human rights instruments recognized by the Office of the United Nations High Commissioner for Human Rights, Elliott (2007) identifies a wide range of social entities whose number vastly expanded since the 1990s. Among these protected groups are children, women, the disabled and refugees.

I argue that these different types of agency are historically successive and recursive (Figure 1). While defending global principles has always been the core mandate of the majority of IOs, particularly the UN, I illustrate that advocacy for natural entities and particular social groups is a more recent phenomenon. Further, relations among world society actors are recursive in that they refer

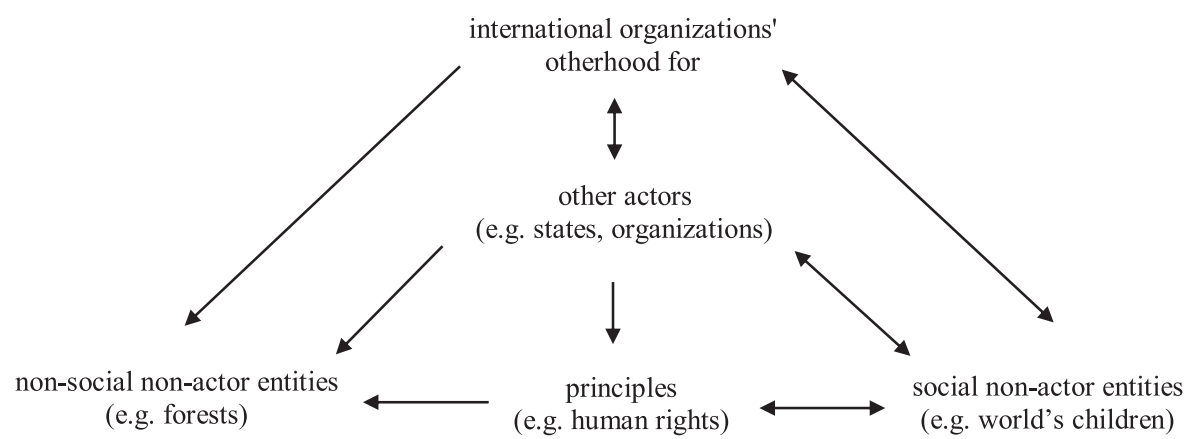

Figure 1. International organizations' otherhood as a mechanism of world society construction. 
to each other in defending their position. IOs call on states to act, while states mandate IOs to address particular issues (e.g. climate change or educational achievement testing). It shall also be noted that powerful states may have a say in particular policy recommendations by IOs (hence the bidirectional arrow in Figure 1).

World society is a multi-actor order and although this study gives analytical primacy to IOs, their impact is both direct and indirect. In most cases IOs act indirectly through states (e.g. national education policies) or as proxy actors on behalf of states (Chabbott, 2003; Meyer et al., 1997). Increasingly, IOs also deal directly with principles, natural phenomena and social groups; for which global reports serve as an important example. Conversely, social groups may refer to IO-promoted principles, notably human rights, or seek IO support in their struggles. Here, non-governmental organizations often defend the social groups at the grass-roots and voice their concerns to intergovernmental organizations and states (Boli \& Thomas, 1999). In some cases, such group-based advocacy may cause overt conflict as interests and rights associated with particular groups are amplified through the action of organized civil society and intergovernmental organizations. Research on ethnic conflicts, for example, shows that these conflicts are not only fuelled by the cultural distance of ethnic groups or economic inequality, but also by the presence of IOs that mobilize collective action to claim rights for ethnic minorities (Olzak, 2006). These examples show that the role of IOs has become crucial at multiple levels of the global governance arena. I argue that with the novel phenomenon of global reporting, IOs' otherhood has become much more visible. The following section seeks to define global reports and to conceptualize these as instances of sector-specific otherhood and an 'imagery' of world society.

\section{Analyzing global reporting}

Global reports need to be understood as rationalized, that is, formal and scientific, and sector-specific accounts of those universal principles and physical and social entities which are seen as an integral part of world society and which require particular attention and action by the key world society actors, namely nation-states and formal international organizations.

Mirroring the general reporting trends at organizational and national levels, where pressures of accountability and quality have led to widespread rationalization and standardization of reporting systems (Bromley \& Meyer, 2015; Drori et al., 2009; Power, 2004), this work treats global reports as a distinctive analytical level. In this, global reports, through otherhood, document the expansive character of world society by reflecting, first, the sectors and, second, the principles and entities considered part of world society. They, third, provide insight into the construction of a novel globalizing arithmetic by introducing aggregated world indicators framing concerns and problems as having planetary and universal relevance. The majority of these reports are not requested nor commissioned by IOs' constituencies (most notably, nation-states). Instead, they reflect a particular effort of 'bureaucratic propaganda' as others in world society (Altheide \& Johnson, 1980) promoting the interests of world society as a whole and urging world society actors to take concerted and rational action in order to tackle problems that matter to all of humanity. The following section elaborates on these arguments and formulates research questions that guide the empirical analysis.

Expansion of sectors. As touched upon above, world society is an expansive institutional order and the growing number of international organizations mirrors the spread of substantive areas recognized as relevant (Boli \& Thomas, 1999; Lechner \& Boli, 2014). In related international relations scholarship, similar expansive trends are treated as the emergence of new international 
regimes and the thickening structures of global governance (Deacon, 2007). Why such expansion occurs has no straightforward answer. In functionalist perspectives (e.g. IR neoliberalism), IOs proliferate where coordination problems emerge, yet for many sectors shown below, no immediate international and governmental action would be required. A more plausible explanation is both the diffusion of rights and shifting norms (e.g. environmentalism) as well as the growing expertise and data availability to monitor normatively-backed goals (Barnett \& Finnemore, 2004). For instance, Zapp (2017a) finds that IOs' scientific research and publication activities now cover twenty different policy sectors, that is, more than doubling the number of issue areas in less than two decades. It is likely that similar sectoral expansion occurs in global reporting activities.

Research question I: What are the world society sectors or governance areas addressed in global reports over time?

Expansion of agency for others. The present study does not only see IOs as 'rationalized others' and reports as instances of 'rationalized othering' but intends to link the rise of global reporting to specific types of agency and the related construction of entities within these reports. The distinction of agency types introduced above helps to reconceptualize IOs as 'others' in world society, and it allows to understand the role of global reports. In relation to IOs' audience, IOs are agents for other actors with reports being written for nation-states, other (international) organizations as well as individuals (e.g. professionals). In relation to objects, (i.e. the themes of reports), IOs act as agents for principles and non-actor entities (both social and non-social) with these reports being written about shared rules, natural and physical phenomena and recognized (yet unorganized) groups that lack the status of proper agents. Global reports take stock of the cultural and social panoply of contemporary world society, most prominently liberty and justice, progress and individualism (Meyer et al., 1997). As instances of otherhood they specify the values and members of that world society. It is, therefore, of particular interest to see the expansive construction of particular principles and entities as they emerge in reports over time.

Research question II: What are the types of agency and related principles and entities represented in global reports over time?

Expansion of world society indicators. Traditionally, statistics emerged as a political arithmetic aiding in the construction of the nation-state (Desrosières, 1991). Counting and accounting and the related 'methodological nationalism' (Beck, 2007) had become important tools to forge the national society as an 'imagined community' (Anderson, 1991). In the post-World War II period, such accounting methods have gradually become a standardized task around the world. For example, Jang et al. (2014), analyzing national reporting activities in relation to the UN in the period 19702000 , find that a growing number of governments report more and more data and that these reports are increasingly in accordance with international standards.

More recently, another shift has occurred. Led by IOs, states increasingly commit themselves to specific goal agendas, often defined through international treaties (or protocols, conventions, and agreements). For example, multilateral environmental treaties have skyrocketed in the 1990s after which more than half of all existing treaties $(N=1,311)$ were signed (Hironaka, 2002; Mitchell, 2002/2019). In other cases, states agree on a specific set of goals for which the Education for All or the Sustainable Development Goals are prominent examples (Zapp \& Ramirez, 2019). Concomitant with such shared goal definition, monitoring activities have sprung up drawing heavily on statistical indicators which increasingly measure progress at both the national, country group (e.g. highincome countries) and even the aggregated world level (e.g. Chabbott, 2003; Lechner \& Boli, 2014). In a rare study of such reporting shifts, Hwang (2006), analyzing the Human Development Report for the year 2000, finds that world level indicators have come to outweigh national and country 
group indicators. Thus, global reports frame issues as global problems requiring global solutions and seem to increasingly draw on various or even produce new levels of analysis to measure the progress toward collective goals. Yet, while all global reports claim to be global in scope, it does not mean that they give ontological standing to the world as a whole in their analysis as would be reflected by employing a global scale in measuring specific concerns.

Research question III: Do reporting practices, namely the use of indicators, and the related levels of aggregation (e.g. national, country groups, global) change during the observation period?

This study seeks to answer these three questions and draws on an original dataset of global reports covering a period of 72 years. The following section introduces the data and analytical tools.

\section{Methodology}

\subsection{Data}

In order to identify global reports, this study draws on the Yearbook of International Organizations (YIO). The YIO is published by the Union of International Associations (UIA; active in the field since 1907) and represents the most comprehensive and authoritative source for the study of all types of international organizations (IOs) (UIA, 2017). The YIO database contains information on IOs' main organizational properties including their publications along with information on publication title as well as year and frequency of publication.

Reports are only included if they represent a periodical or recurring publication. Single-year reports of global scale were excluded. This strategy was chosen because the study is interested in documenting institutionalized or recognized domains of world society. I acknowledge that this selection strategy is conservative and omits many nonrecurring publications. Based on YIO information, another 334 reports are, thus, excluded from the analysis as they were published only once. However, in order to trace the institutionalization and development of specific global discourses and to warrant comparability over time, I consider indispensable the inclusion of reports that reflect a lasting interest by the international community. Search for reports was based on keywords from report titles including general terms that suggest a universal coverage such as 'world', 'global', 'earth', 'planet', 'international', 'human', 'countries', and 'development'. I argue that these terms indicate reporting activities with a global ambition. Global reporting has no specific national or regional foci but signals its global scope by presenting discussion of global phenomena, global data, and, in cases where individual countries or regions are highlighted, embeds these local instances into a global frame.

Reports were then downloaded manually from the organization's official website, acquired through the library system or, in some cases, purchased individually and, then, thoroughly assessed for their global scope. Whenever more than one organization authors a report, reports are counted once while authorship is assigned to both organizations. Organizational types (e.g. IGO vs INGO) are taken from the YIO definition. The final sample contains $N=110$ reports issued by $N=63$ international organizations. I acknowledge that not all reports of potentially global scope are covered by these search terms. Reports may also have changed their coverage (and title) over time and may, at an earlier point, have been more limited. Again, others might simply not refer to a global (or related) coverage in their title, while providing such coverage in their content. However, I hold that such systematic data collection through an official source warrants greater validity and that the cautious inclusion of reports ensures that the sample consists of genuinely global formats. 


\subsection{Analysis}

Analysis follows a three-step process (see Appendix for coding frameworks). In the first step, reports were aggregated to sectoral categories based on thematic similarity (e.g. human rights \& democracy \& law). Sectoral categories partly stem from UIA's (UIA, 2017) definitions and, partly, represent original coding families retrieved through qualitative analysis of reports (Corbin \& Strauss, 2008; Glaser, 1992) and informed by previous research on IOs' sector-specific activities (Zapp, 2017a; Boli \& Thomas, 1999; Deacon, 2007). This sample of reports is represented by $N=$ 15 coding families or sectoral categories (see Appendices for a full list of reports, IOs and analytical categories).

Reports were then assigned to the three-fold typology of agency introduced above. Agency types first include agency for abstract principles. For example, Scholar at Risk's Academic Freedom Monitoring Report was coded as linked to the principle of academic freedom. Second, reports are assigned to agency for non-social, natural or physical entities for example, UNEP's Biodiversity Outlook. Third, reports may refer to agency for aggregate social non-actor groups without agency status such as the Loomba Foundation's Global Widows Report. Further coding sought to specify those principles and entities explicitly analyzed and discussed as national, regional or global. In most cases, these are depicted through indicators, indices or other statistical measures. For example, after linking 'agency for social entities' to the sector code 'human development \& empowerment', the final step identifies the 'global total of widows' as the specific entity discussed and statisticallytreated as 'global' in the report.

Supported by the software MAXQDA, reports were coded manually one-by-one and page-bypage. I acknowledge that some cases entail blurry typological boundaries both for sectoral categories and agency types. Overlapping sectoral categories include, for example, the Global Report on Food Crises by the World Food Programme, which was coded as part of the agriculture \& food category instead of the humanitarian \& crisis category. Some reports also represent overlapping types of agency. The Academic Freedom Report by Scholars At Risk was coded as agency for principle (academic freedom) although one might argue that it refers to agency for scientists as an example of a social non-actor entity. Given the complex multidimensionality of these vast areas of human concern addressed in these reports, I consider such analytical overlap inevitable. Table 1 presents a sample description of reports and authoring organizations. Reports span a period of 72 years, with the year 2014 being the year with the highest publication count. The vast majority of reports have been published by intergovernmental organizations. The UN (with $N=63$ reports) and the Food and Agriculture Organization (with $N=12$ reports) are particularly pronounced followed by nongovernmental organizations as well as for-profits, international research institutes and other bodies (such as networks and forums).

Table 1. Sample description.

\begin{tabular}{|c|c|c|c|c|c|}
\hline & $\mathrm{N}$ & mean & $\min$ & $\max$ & modal year \\
\hline $\begin{array}{l}\text { year of first publication } \\
\text { organizational type }\end{array}$ & 110 & 2004 & 1947 & 2019 & 2014 \\
\hline inter-governmental & 36 & 57.1 & & & \\
\hline international non-governmental & 16 & 25.4 & & & \\
\hline for-profit & 4 & 6.4 & & & \\
\hline international research institutes & 4 & 6.4 & & & \\
\hline other IOs & 3 & 4.7 & & & \\
\hline
\end{tabular}




\section{Findings: the rise of global reporting}

The result section is organized around the three research questions introduced above. First, I present the expansion of global reports in general and by sectors in particular. Next, I trace the expansion of global reports by type of agency and related principles and entities. In the final section, I present findings from the analysis of indicator usage over time by level of aggregation.

\subsection{Expansion of sectors}

The number of reports grows slowly until the early 1990s when publications soar up and remain steady during the two subsequent decades before slowing down in the mid-2010s (Figure 2). The first global report appears in 1947 with FAO's The State of Food and Agriculture, followed by Amnesty International's Annual Human Rights Report (1961). The most recent reports (2019) in the sample include FAO's State of the World's Biodiversity for Food and Agriculture, the UN Global Report on Environmental Rule of Law and the Intergovernmental Science-Policy Platform on Biodiversity and Ecosystem Services' Global Assessment Report on Biodiversity and Ecosystem Services.

While the expansive trend is a general phenomenon, reports vary according to governance sectors. Table 2 shows the prevalence of reports by these sectors and tracks their expansion during the observation period. While democracy, law and human rights as well as agriculture and food represent the earliest domains of global reporting, human development and empowerment account for the largest group over time $(N=25)$. The UN Human Development Report, UNICEF's The State of the World's Children and more recently, the Loomba Foundation's Global Widows Report are some examples of reports from this sector. Reports covering issues of environment, biodiversity and animal rights $(N=13)$, health and well-being as well as economic issues also represent strong sectors $(N$ $=10$ respectively) with momentum since the late 1990s. Sectors that appeared more recently in

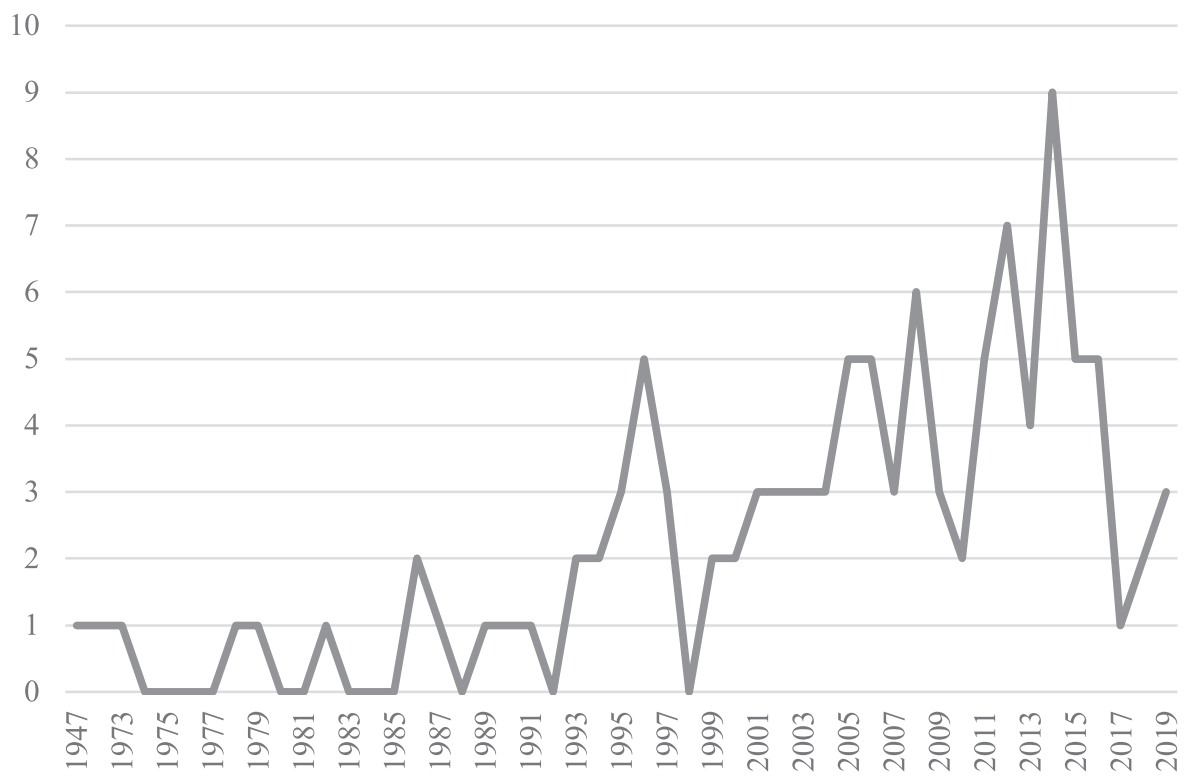

Figure 2. Publication of global reports, by year of first edition, 1947-2019. 
Table 2. The expansion of sectors, by years of appearance, 1945-2019.

\begin{tabular}{|c|c|c|c|c|c|c|c|c|c|c|c|}
\hline & $\begin{array}{l}1947- \\
1965\end{array}$ & $\begin{array}{c}1966- \\
1975\end{array}$ & $\begin{array}{c}1976- \\
1985 \\
\end{array}$ & $\begin{array}{c}1986- \\
1990\end{array}$ & $\begin{array}{c}1991- \\
1995 \\
\end{array}$ & $\begin{array}{l}1996- \\
2000\end{array}$ & $\begin{array}{c}2001- \\
2005\end{array}$ & $\begin{array}{l}2006- \\
2010\end{array}$ & $\begin{array}{c}2011- \\
2015\end{array}$ & $\begin{array}{c}2016- \\
2019\end{array}$ & total \\
\hline $\begin{array}{l}\text { democracy, law \& } \\
\text { human rights }\end{array}$ & 1 & 1 & & 1 & & 2 & & 1 & 3 & 1 & 10 \\
\hline agriculture \& food & 1 & & & 1 & & 1 & & & 1 & & 4 \\
\hline $\begin{array}{l}\text { human development } \\
\& \text { empowerment }\end{array}$ & & & 1 & 2 & 1 & 3 & 3 & 4 & 10 & 1 & 25 \\
\hline $\begin{array}{l}\text { macro-economic, } \\
\text { finance, trade }\end{array}$ & & & 1 & & 2 & 1 & 2 & 2 & 1 & 1 & 10 \\
\hline $\begin{array}{l}\text { security \& safety \& } \\
\text { crime prevention }\end{array}$ & & & 1 & & & 1 & 1 & 3 & 1 & & 7 \\
\hline health \& well-being & & & & 1 & 1 & 1 & 3 & 1 & 2 & 1 & 10 \\
\hline energy \& resources & & & & 1 & & & 2 & 2 & 1 & & 6 \\
\hline $\begin{array}{l}\text { environment, } \\
\text { biodiversity \& animal } \\
\text { rights }\end{array}$ & & & & & 2 & 2 & 1 & 2 & 3 & 3 & 13 \\
\hline humanitarian \& crisis & & & & & 1 & & & 1 & & 1 & 3 \\
\hline culture & & & & & 1 & & & 1 & & & 2 \\
\hline $\begin{array}{l}\text { migration, mobility \& } \\
\text { tourism }\end{array}$ & & & & & & 1 & 1 & 1 & 3 & 1 & 7 \\
\hline education \& science & & & & & & & 2 & 2 & & & 4 \\
\hline ICT & & & & & & & 1 & 1 & 3 & & 5 \\
\hline work & & & & & & & 1 & & 2 & & 3 \\
\hline political integration & & & & & & & & 1 & & & 1 \\
\hline Total & 2 & 1 & 3 & 6 & 8 & 12 & 17 & 22 & 30 & 9 & 110 \\
\hline
\end{tabular}

reports include education and science, ICT - and perhaps surprisingly given the ILO's long history work.

\subsection{Expansion of agency and related principles and entities}

Turning to agency types represented by reports, a focus on general principles marks the early period of global reporting (Figure 3). The aforementioned FAO's The State of Food and Agriculture in 1947

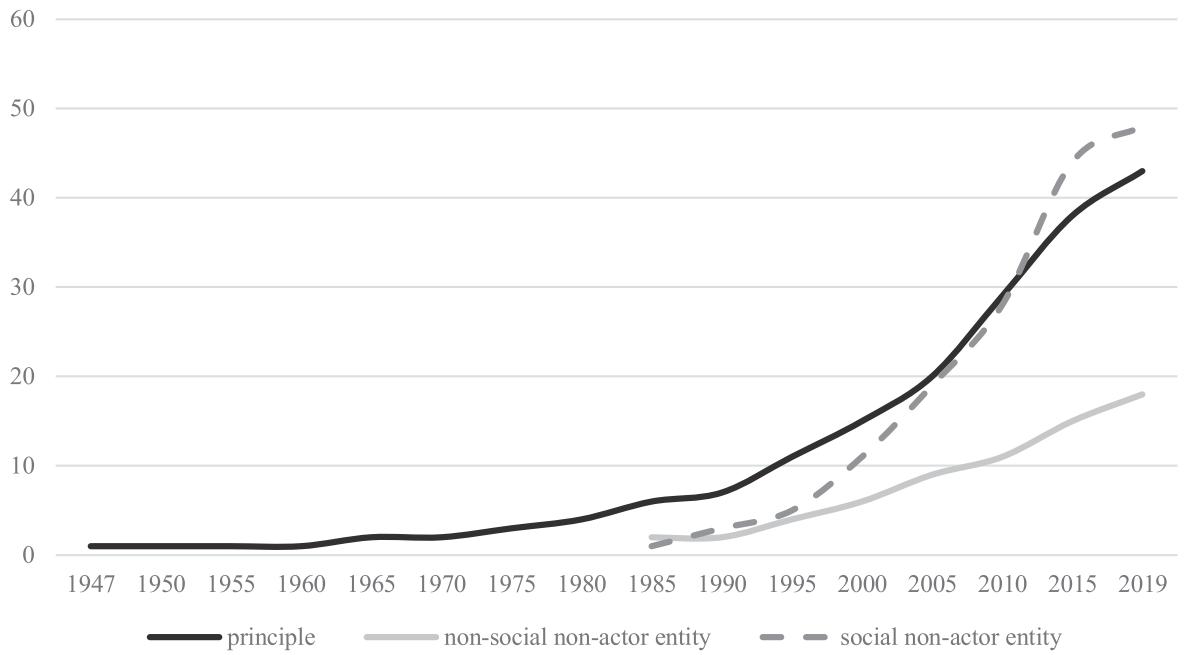

Figure 3. Expansion of global reports by type of agency, 1947-2019 ( $N=110$; cumulative count). 
and AI's Annual Human Rights Report (1961) are examples for such principle-oriented accounts. These reports expand slowly up to the 1980s after which their numbers double per each decade. Some important reports on general principles appear in the 1990s for the first time including the first World Disasters Report (Red Cross; 1993) and World Health Report (World Health Organization, WHO; 1995). The expansion of principle-related reports remains steady (albeit at a higher level) up to the end of the observation period. The International Labour Organization's (ILO) World Employment and Social Outlook Report (2016) and the UN's Global Report on Environmental Rule of Law (2019), are prominent examples of such publications in the more recent period.

In the mid-1980s, reports that cover non-social entities appear for the first time. For example, the World Resource Report by the non-governmental World Resource Institute is published in 1986. Growth of these reports receives considerable momentum in the 1990s. Reports such as the State of World Fisheries and Aquaculture (1994), State of The World's Forests (1995), State of the World's Plant Genetic Resources for Food and Agriculture (1996), and the State of Food Insecurity in the World (1999), are examples of such 'flagship' publications (all by the FAO). The upward trend remains strong until today with the International Whaling Commission's Biennial Reports (2014) and (again), the FAO's report on the State of the World's Biodiversity for Food and Agriculture (2019).

Reports that address particular social groups also burgeon in the mid-1980s with the International Food Policy Research Institute's Global Food Policy Report (1986). This report explicitly addresses the situation of undernourished populations (as opposed to the systemic perspective of food security presented in the earlier FAO report). Reports on social entities, while virtually absent until the 1990s, show striking expansion in that decade and even more so since the millennium. In the past two decades, the number of reports that represent a wide range of social groups increased by a factor of four and now account for the majority of all reports $(N=48)$. Among the most recent group-related reports, we find the United Nations World Tourism Organization's (UNWTO) Global Report on Inclusive Tourism Destination' (2018) and the non-governmental World Federation of the Deafblind's (WFDB) Global Report on Deafblindness (2018).

Whereas sectors and agency types constitute aggregated units of analysis, global reports concentrate on particular thematic foci. Based on within-report content analyses, Tables 3-5 present these

Table 3. The expansion of principles in global reports, by years of appearance, 1945-2019.

\begin{tabular}{|c|c|c|c|c|c|c|c|c|c|c|c|}
\hline & $\begin{array}{c}1947- \\
1965\end{array}$ & $\begin{array}{c}1966- \\
1975\end{array}$ & $\begin{array}{c}1976- \\
1985\end{array}$ & $\begin{array}{c}1986- \\
1990\end{array}$ & $\begin{array}{c}1991- \\
1995\end{array}$ & $\begin{array}{c}1996- \\
2000\end{array}$ & $\begin{array}{c}2001- \\
2005\end{array}$ & $\begin{array}{c}2006- \\
2010\end{array}$ & $\begin{array}{c}2011- \\
2015\end{array}$ & $\begin{array}{c}2016- \\
2019\end{array}$ & $N$ \\
\hline fighting hunger & 1 & & & & & & & & & & 1 \\
\hline human rights & 1 & 1 & & 1 & & 1 & & 1 & 3 & 1 & 9 \\
\hline $\begin{array}{l}\text { equality \& fighting } \\
\text { poverty }\end{array}$ & & & 1 & & & & & & 2 & 2 & 5 \\
\hline economic growth & & & 1 & & 2 & 2 & 1 & 1 & 1 & 1 & 9 \\
\hline security & & & 1 & & & 1 & 1 & 2 & 1 & & 5 \\
\hline energy \& resources & & & & & & & 1 & & & & 1 \\
\hline $\begin{array}{l}\text { environmental } \\
\text { protection/ } \\
\text { sustainability }\end{array}$ & & & & & & & & & & 2 & 2 \\
\hline health \& happiness & & & & & 1 & & 1 & 1 & & & 3 \\
\hline humanitarian aid & & & & & 1 & & & 1 & & & 2 \\
\hline internet connectivity & & & & & & & 1 & 1 & 2 & & 4 \\
\hline regionalization & & & & & & & & 2 & & & 2 \\
\hline $\begin{array}{l}\text { work \& social } \\
\text { protection }\end{array}$ & & & & & & & 1 & & & & 1 \\
\hline$N$ & 2 & 1 & 3 & 1 & 4 & 4 & 6 & 9 & 10 & 4 & 44 \\
\hline
\end{tabular}


Table 4. The expansion of non-social entities in global reports, by years of appearance, 1986-2019.

\begin{tabular}{|c|c|c|c|c|c|c|c|c|}
\hline & 1986-90 & 1991-95 & 1996-00 & 2001-05 & $2006-10$ & 2011-15 & 2016-19 & $N$ \\
\hline resources & 1 & & & 2 & & 2 & & 5 \\
\hline cities & 1 & & & & & & & 1 \\
\hline fish & & 1 & & & & & & 1 \\
\hline forests & & 1 & & & & & & 1 \\
\hline environment in general & & & 1 & & 1 & & & 2 \\
\hline (crop) plants & & & 1 & & & 1 & 1 & 3 \\
\hline water & & & & 1 & & & & 1 \\
\hline fauna in general & & & & & 1 & & 2 & 3 \\
\hline whales & & & & & & 1 & & 1 \\
\hline $\mathrm{N}$ & 2 & 2 & 2 & 3 & 2 & 4 & 3 & 18 \\
\hline
\end{tabular}

foci as the specific agency-related principles, non-social as well as social entities in a historical perspective.

Principles of food security and human rights mark the early reporting period up to the mid-1970s before issues of equality and poverty reduction, economic growth and security (as peace-building) enter the reporting system (Table 3). Health and humanitarian aid are highlighted in the first half of the 1990s. Only in the early 2000s do new issues start to become included. Some of these issues include work and social protection, internet access, and energy and resources. The decade 20062015, the most prolific period, sees additional reports published that cover already established topics such as human rights and economic growth.

Reports that address non-social entities burgeon in the mid-1980s and the first of these reports discusses the status of natural resources in relation to the world's cities (Table 4). The situation of fish and forests is discussed in the early 1990s before important reports appear that address the environment more generally (e.g. UN Global Environment Outlook) and food crops in particular (e.g. FAO's Report on the State of the World's Plant Genetic Resources for Food and Agriculture).

Table 5. The expansion of social entities in global reports, by years of appearance, 1986-2019.

\begin{tabular}{|c|c|c|c|c|c|c|c|c|}
\hline & 1986-1990 & 1991-1995 & 1996-1900 & 2001-2005 & 2006-2010 & 2011-2015 & 2016-2019 & $N$ \\
\hline undernourished & 2 & & 1 & & & & 1 & 3 \\
\hline general human population & 1 & & & 2 & 1 & 3 & & 7 \\
\hline cultural minorities & & 1 & & & 2 & & & 3 \\
\hline least developed countries & & 1 & & & & & & 1 \\
\hline migrants/ refugees & & & 1 & 1 & & 1 & & 3 \\
\hline children/ youth & & & 1 & & 1 & 3 & & 5 \\
\hline drug addicts & & & 1 & & & & & 1 \\
\hline human settlements & & & 1 & & & & & 1 \\
\hline the poor & & & 1 & & & & & 1 \\
\hline learners & & & & 1 & 1 & & & 2 \\
\hline elderly & & & & 1 & & & & 1 \\
\hline HIV patients & & & & 1 & & & & 1 \\
\hline scientists & & & & 1 & & & & 1 \\
\hline victims of violence & & & & 1 & & & & 1 \\
\hline women & & & & & 1 & 3 & & 4 \\
\hline workers & & & & & 1 & 2 & & 3 \\
\hline social scientists & & & & & 1 & & & 1 \\
\hline victims of human trafficking & & & & & 1 & & & 1 \\
\hline disabled & & & & & & 2 & 2 & 4 \\
\hline journalists & & & & & & 1 & & 1 \\
\hline LGBT & & & & & & 1 & & 1 \\
\hline diabetes patients & & & & & & & 1 & 1 \\
\hline$N$ & 3 & 2 & 6 & 8 & 9 & 16 & 4 & 48 \\
\hline
\end{tabular}


Reports of this type diversify in the past decade covering both general (fauna) and more specific entities (e.g. whales).

Parallel to the emergence of reports on natural or physical entities, social entities also spring up in the mid-1980s. Early reports of this type address the state of the human population in general (e.g. the UN Human Development Report) or the condition of the undernourished human population in particular (e.g. International Food Policy Research Institute's Global Food Policy Report).

Cultural and ethnic minorities as well as least developed societies are addressed in the early 1990s for the first time. The second half of the 1990s sees the launch of numerous group-related reports focusing on migrants, children, drug addicts, and impoverished communities. Similarly, in the following quinquennial, another wave of reports address learning and elderly populations as well as HIV patients, scientists and victims of violence. During the past decade, people with special needs are given considerable attention as well as journalists, the LGTBQ community and diabetes patients.

\subsection{Expansion of reporting activities}

Finally, I turn to the evolution of indicators used in global reports. Reports were analyzed in terms of levels of aggregation of indicators and the changes in such practices over time. Table 6 tracks these reported indicators over the past 72 years.

The earliest reports use no or very few indicators. The aforementioned FAO report on The State of Food and Agriculture (1947) and the AI Human Rights Report (1961) resemble short summaries of organizational functions and positions and do not present any data at all. Freedom House's maiden edition of Freedom in the World (1973) is the first report to use empirical indicators, yet still framed in a country perspective. The WB's first World Development Report (1978) uses both country and group data (e.g. low-income countries).

By contrast, global reports published for the first time in the more recent period show markedly different indicator practices. More than half of those first-issue reports produced in the 1990s already report on country, country group and world levels. The share of those all-encompassing reports increases to roughly $82 \%$ by the end of the 2010 s. This while the number of reports that consider only national, or national and country group levels, decreases considerably (to only $9.1 \%$ for the latter) or, in the case of exclusively country-based indicators, completely disappear.

Since the mid-1990s, it has become a routine practice to report on 'world growth' and 'world trade volume' (e.g. the IMF's World Economic Outlook), a 'global GDP' (e.g. the WB's World

Table 6. Reported indicators by level of aggregation, $1945-2019, \%$ of first issue reports $(N=110)$.

\begin{tabular}{|c|c|c|c|c|c|c|c|c|c|c|}
\hline & $\begin{array}{c}1947- \\
1965\end{array}$ & $\begin{array}{c}1966- \\
1975\end{array}$ & $\begin{array}{c}1976- \\
1985\end{array}$ & $\begin{array}{c}1986- \\
1990\end{array}$ & $\begin{array}{c}1991- \\
1995\end{array}$ & $\begin{array}{l}1996- \\
2000\end{array}$ & $\begin{array}{c}2001- \\
2005\end{array}$ & $\begin{array}{c}2006- \\
2010\end{array}$ & $\begin{array}{c}2011- \\
2015\end{array}$ & $\begin{array}{c}2016- \\
2019\end{array}$ \\
\hline no indicators & 100 & & & & & & & & & \\
\hline only national & & 100 & 66.7 & 33.3 & & 16.7 & 11.7 & 5 & & \\
\hline $\begin{array}{l}\text { only country } \\
\text { groups }\end{array}$ & & & & & & & & 5 & 4.3 & \\
\hline only world & & & & & & & & & & \\
\hline $\begin{array}{l}\text { national + country } \\
\text { groups }\end{array}$ & & & 33.3 & 66.7 & 50 & 16.7 & 5.9 & 15 & 13 & 9.1 \\
\hline national + global & & & & & & & 5.9 & & 13 & \\
\hline $\begin{array}{l}\text { country groups + } \\
\text { world }\end{array}$ & & & & & & 8.3 & 5.9 & & & 9.1 \\
\hline all three levels & & & & & 50 & 58.3 & 70.6 & 75 & 69.7 & 81.8 \\
\hline$N$ of reports & 2 & 1 & 3 & 6 & 8 & 12 & 17 & 22 & 30 & 9 \\
\hline
\end{tabular}


Development Report), and the 'global unemployment rate' (e.g. the ILO's World Employment and Social Outlook Report). We know about the 'total number of high casualty terrorist bombings worldwide' (CSP's Global Report on Conflict, Governance and State Fragility), the 'global total for livestock breeds' (FAO's State of the World's Animal Genetic Resources for Food and Agriculture), the 'renewable energy contribution to global primary energy' (REN21's Renewables Global Status Report), and the 'global distribution of life satisfaction of the human population' (UN World Happiness Report). We also learn that 'the world has developed only $62 \%$ of its human capital (WEF's Global Human Capital Report 2017, p. vii) and it now seems effortless to gauge a global diabetes prevalence rate (WHO's Global Diabetes Report), to count the global number of species of flowering plants (FAO's Report on The State of the World's Plants), the number of female landholders worldwide (FAO's Status of the World's Soil Resources), and to measure income inequality between individuals worldwide as a measure of global inequality (UNESCO's World Social Science Report). ${ }^{1}$ Language and methodologies also change. 'All member states' suddenly become 'world totals' or simply 'world' (e.g. comparing WHO's WHR edition 1996 and 1997). Since the mid-1990s, countries often become case studies or places where particular attention and action is needed (e.g. low internet user rates in Tanzania, threats to biodiversity in Brazil, high diabetes rates in Tuvalu) and which are then measured against the 'rest of the world' (e.g. shootings in schools in the USA vs. the rest of the world in ICPC's International Report on Crime Prevention and Community Safety).

How do the same reports change over time? While Table 6 examines only the first editions of reports spanning more than 70 years of reporting, it can be assumed that the same reports also change across observation intervals, that is, those reports that did not use any indicators may begin to use these at a later point. Further, reports that use indicators at a particular level (e.g. national) may change their scope and shift indicators upward or downward. Table 7 below tracks indicator practices for those $N=33$ reports that had not used indicators at all or used indicators below the world-aggregated level in an earlier (first-issue) period.

At the end of the observation period, only $N=6$ reports (5\%) have not undergone a shift in reporting practices and continue to make no use of global indicators (Table 7). These include some reports which are evidently (and exclusively) regional in their scope (e.g. UNO-CRIS' World Report on Regional Integration) but also some important human rights and in general legal reports (AI's and Human Rights Watch's reports, UN Global Report on Environmental Rule of Law) which remain below global aggregation in their use of reported indicators.

Importantly, by the early 2000s, the vast majority of reports includes a global aggregation level. $N$ $=97$ reports $(88 \%)$ of reports refer to all or at least two levels of aggregation including the world level. No report shows a shift downwards in aggregation (e.g. from world to groups to countries).

Table 7. Changes in reported indicators by level of aggregation and mean year.

\begin{tabular}{llrc}
\hline & & N & mean year \\
\hline from none/ national to & national + country groups & 5 & 1996 \\
from none/ national to & only country groups & 2 & 2016 \\
from none/ national to & all & 20 & 2002 \\
from national + country groups to & no change & 6 & $/$ \\
$N$ of reports & & 33 & \\
\hline
\end{tabular}




\section{Discussion: reporting as global otherhood and discursive globalization}

Global reports have seen striking proliferation since the 1990s. Virtually all domains of human activity are now deemed global sectors and treated as such through the production of related global reports. Testimony to the expansive character of the reporting system in the latter half of the twentieth century (research question I), reporting covers at least one new sector every five years reflecting the strong dynamism in world society (Drori et al., 2003). The strongest sectors, i.e. those addressed by multiple reports, include human development, environmental issues, human rights and health as well as the global economy. This is not surprising as these sectors represent the core of world society. Human development and empowerment have become the overriding priority in global policymaking since their prioritization in the 1990s (Chabbott, 2003). The appreciation and protection of nature has long been a key item on the international agenda, even more so since the beginning of the sustainable development agenda (Hironaka, 2002; Mitchell, 2019; Shandra, 2007). Human rights constitute the backbone of world culture as documented in a number of studies (Cole, 2016; Elliott, 2007) and economic thinking has gradually been institutionalized as a global discourse and professional activity during the second half of the twentieth century (Fourcade, 2006). At the same time, some sectors receive little attention or have given attention only very recently, notably the work or labour sector. With the ILO being one of the oldest IOs in the sample, the first global report on work (not on social security though) was published only in the past 5 years, perhaps reflecting less the increasingly globalized nature of labour markets but the strong primacy of national labour policymaking.

In explaining the rise and role of global reports in world society, this work stresses the concept of otherhood and the three related types of agency as mechanisms of world society construction and integration (Meyer, 2019; Meyer \& Jepperson, 2000). The different types of otherhood are helpful in explaining the spread of reports in the post-1990 era especially when seen as interdependent (research question II). I will elaborate on this argument in the following sections.

It is telling that those reports that emerged in the post-WW II period focused exclusively on principles and that these reports did not make any use of indicators. Human and planetary concern (both individual or aggregated) remained an abstract notion until the mid-1980s when non-actor entities (of both the non-social and social kinds), were given first attention. Although reports on principles also multiply in the more recent period and remain the second strongest group of reports, they often resemble normative charters awash with pleas for action. These principles prepare the moral and legal ground on which advocacy for specific entities can grow.

For example, the ample legal regime of human rights, with the Universal Declaration at its core and numerous covenants and conventions being added to it until today, provides an almost infinite basis for reporting on progress in civil, political, economic, social and cultural rights (Cole, 2016). The striking increase in the largest group of reports - those that address humanity in general and social groups in particular - coincides with global discourses on human rights and empowerment and the related 'cult of the individual' (Elliott, 2007). Here, reports that address particular groups whose rights are systematically denied become means of integration into world society. Women, children, the undernourished, refugees, LGTBQ groups and people with special needs, in short, all those groups seen as disadvantaged or deprived of their rights are drawn into the focus of world society. Reports here, become tools of empowerment instilling world society with foundational principles and legitimizing the entitlements of natural and social entities previously seen as passive and subject to national sovereigns (Meyer, 2019; Meyer \& Jepperson, 2000). 
The role of measurable goals and related indicators and data is crucial (research question III). Decades of cross-national standardization efforts make genuinely global reports feasible. Key elements of reporting such as terminology, methodology, data, policy goals and related evaluations - in short, a shared frame of analysis underlying any formal report - had become increasingly globalized (Jang et al., 2014). Yet, it was only in the post-Cold War period that a wave of global conferences led to the definition of shared goals in such areas as children, women, education, human rights, nutrition, etc., which made global reports necessary (e.g. Chabbott, 2003). With the intensification of international conferencing and agenda-setting in the past two decades, more and more collective goals enter the global discourse. For example, while the Millennium Development Goals (2000) included eight goals, the more recent Sustainable Development Goals (2015) refer to 17 of such global objectives and 169 related targets.

Importantly, once data can be reliably compared and goals are shared across countries, principles and entities become dis-embedded from their local context (Hwang, 2006). The local, culturespecific or national construct of the 'widow', thus, becomes a universal and global cultural category with all widows worldwide being considered having the same needs, concerns and requiring the same attention and help. As a consequence, the 'global number of widows' suddenly becomes a meaningful descriptor with universal ontological status.

Such decontextualization implies another consequence. I argue that highly aggregated world level indicators in global reports reflect and intend to transmit global consciousness. They deliberately depict the human race as a world society with a common destiny, evoking an 'imagined community' (Anderson, 1991) and creating a 'global public sphere' where the man-made risks of modernity are discussed and analyzed (Beck, 2009) and where all individuals are considered equipped with rights and capabilities to intervene in the course of history (Elliott, 2007). As in earlier nation-state building, communication and media are key in forging these social communities. In contemporary world society, global reports are examples of the institutionalization of global (professional) discourses and their dissemination is astonishing. Almost all of the reports from the sample are freely available, quick to download, aesthetically polished and professionally promoted. Note, for example, the amplitude of diffusion of some of the more prominent reports. UNESCO's Global Education Monitoring Reports or WB's Global Development Reports, for example, are translated into dozens of languages, with downloads in their millions, and come with additional social media coverage as well as related podcasts, blogs and apps. Reports serve as teaching material in universities but also in-house training, professional workshops, and ministerial meetings. Policymakers, professionals and practitioners worldwide draw on these reports and their scientific rigor to legitimize their actions (Zapp, 2017b, 2020).

While country linkages to IOs have often been operationalized as 'receptor sites' for the diffusion of world culture in previous empirical research (e.g. Frank et al., 2000; Lerch, 2019), it can be argued that global reports serve as the primary means of direct communication. It goes without saying that such outreach and coverage does not necessarily lead to policy change, at the same time, it makes further investigation into the ideological and epistemic paradigms of authoring IOs a crucial task in future research (e.g. Dethier, 2007; Rao \& Woolcock, 2007; Ravallion \& Wagstaff, 2012). In the same vein, further research will benefit from in-depth qualitative analyses of these reports, their substantive, lexicometric and scientometric changes to identify longitudinal discursive patterns (e.g. Schaub et al., 2017).

In its entirety, global reports might be seen as the institutionalization of a coherent global monitoring system. Ironically, despite the centrality of the UN system, this monitoring system reflects the decentralized and associational nature of world society. Authoring organizations and their reports 
may, certainly, relate to each other, yet their variety and multitude (in sectors and organizational types) implies that they are produced independently of each other. In the absence of a centralized control system or a 'world development plan', more conferences, goals and related indicators as well as organizations and reports are likely to be generated in the future, keeping world society in the expansive, yet unstable state it has always been. Such instability might only threaten expansion if the core ideals and organizational infrastructure of world society are undermined. Recent surges in illiberal, nationalist and anti-globalization ideology in many countries around the world (Schofer et al., 2018) might then help explain why the number of reports level off in the past five years and would, perhaps, foreshadow a phase of world society contraction.

\section{Conclusion}

Global reporting has become a widespread phenomenon in the more recent period. A diverse field of international organizations including intergovernmental, non-governmental, research and for-profit organizations have started to publish reports of global scope in a wide array of governance sectors. The number of global reports has dramatically increased since the 1990s now standing at 110 global reports covering 15 global sectors. This work argues that global reports need to be understood as instances of otherhood, reflecting agency for other actors, principles and non-actor entities. After decades of standardization and international goal-setting, global reports aggregate the analysis of human activity to the global scale and create an unprecedented level of planetary awareness and discourse. However, in the very recent period, the dynamism has slowed down and might reflect the rise of illiberal forces opposed to further world society expansion.

Note

1. In general, the number of indicators increases dramatically over time. Initially, the author intended to collect data on the total number of indicators used over time to measure overall proportion of indicator levels, yet the emergence of a dizzying myriad of thousands of indicators in the past two decades makes such an analysis a daunting task.

\section{Disclosure statement}

No potential conflict of interest was reported by the author(s).

\section{Notes on contributor}

Mike Zapp is a post-doctoral researcher at the Institute of Education and Society, Université du Luxembourg. Before joining UL, he worked as a fellow at Johns Hopkins University and Stanford University and held a prior post-doc position at UL within the project The New Governance of Educational Research. His research is interested in institutional change in (global) (higher) education, international organizations and global governance.

\section{References}

Altheide, D. L., \& Johnson, J. M. (1980). Bureaucratic propaganda. Allyn and Bacon.

Anderson, B. R. O. G. (1991). Imagined communities: Reflections on the origin and spread of nationalism (Revised and extended ed.). Verso.

Barnett, M., \& Finnemore, M. (2004). Rules for the world: International organizations in global politics. Cornell University Press. 
Beck, U. (2007). The cosmopolitan condition: Why methodological nationalism fails. Theory, Culture \& Society, 24(7-8), 286-290. https://doi.org/10.1177/02632764070240072505

Beck, U. (2009). World at risk (The English ed. Cronin C). Polity.

Beck, U., Bonss, W., \& Lau, C. (2003). The theory of reflexive modernization: Problematic, hypotheses and research programme. Theory, Culture \& Society, 20(2), 1-33. https://doi.org/10.1177/0263276403020002001

Boli, T., \& Thomas, G. M. (1999). INGOs and the organization of world culture. In T. Boli \& G. M. Thomas (Eds.), Constructing world culture: International nongovernmental organizations since 1875 (pp. 13-49). Stanford University Press.

Bromley, P., \& Meyer, J. W. (2015). Hyper-organization: Global organizational expansion. Oxford University Press.

Chabbott, C. (2003). Constructing education for development: International organizations and education for All. Routledge Falmer.

Cole, W. M. (2016). Human rights and the individual: Cross-cultural variation in human rights scores, 1980 to 2010. Social Forces, 95(2), 721-752. https://doi.org/10.1093/sf/sow078

Corbin, J., \& Strauss, A. (2008). Basics of qualitative research (3rd ed.). Sage.

Deacon, B. (2007). Global social policy and governance. Sage.

Desrosières, A. (1991). How to make things which hold together: Social science, statistics, and the state. In P. Wagner, B. Wittrock, \& R. Whitley (Eds.), Discourses on society: The shaping of the social science disciplines (pp. 196-217). Kluwer.

Dethier, J. J. (2007). Producing knowledge for development: Research at the World Bank. Global Governance: A Review of Multilateralism and International Organisations, 13(4), 469-478. https://doi.org/10.1163/ 19426720-01304002

Drori, G. S., Meyer, J. W., \& Hwang, H. (Eds.). (2009). Globalization and organization. Oxford University Press.

Drori, G. S., Meyer, J. W., Ramirez, F. O., \& Schofer, E. (2003). Science in the modern world polity: Institutionalization and globalization. Stanford University Press.

Elliott, M. A. (2007). Human rights and the triumph of the individual in world culture. Cultural Sociology, 1(3), 343-363. https://doi.org/10.1177/1749975507082052

Finnemore, M., \& Sikkink, K. (1998). International norm dynamics and political change. International Organization, 52(4), 887-917. https://doi.org/10.1162/002081898550789

Fourcade, M. (2006). The construction of a global profession: The transnationalization of economics. American Journal of Sociology, 112(1), 145-194. https://doi.org/10.1086/502693

Frank, D., Hironaka, A., \& Schofer, E. (2000). The nation-state and the natural environment over the twentieth century. American Sociological Review, 65(1), 96-116. http://www.jstor.org/stable/2657291 https://doi.org/ $10.2307 / 2657291$

Glaser, B. G. (1992). Basics of grounded theory: Emergence vs. Forcing. Sociology Press.

Hironaka, A. (2002). The globalization of environmental protection: The case of environmental impact assessment. International Journal of Comparative Sociology, 43(1), 65-78. https://doi.org/10.1177/ 002071520204300104

Hwang, H. (2006). Planning development: Globalization and the shifting locus of planning. In G. S. Drori, J. W. Meyer, \& H. Hwang (Eds.), Globalization and organization (pp. 69-90). Oxford University Press.

Jang, Y. S., Cho, M., \& Drori, G. S. (2014). National transparency: Global trends and national variations. International Journal of Comparative Sociology, 55(2), 95-118. https://doi.org/10.1177/0020715214534949

Krücken, G., \& Drori, G. S. (Eds.). (2009). World society: The writings of John W. Meyer. Oxford University Press.

Lechner, F. J., \& Boli, J. (2014). The globalization reader (5th ed.). Blackwell Publishers.

Lerch, J. C. (2019). INGO memberships revisited: Local variation of receptor sites in the education sector. International Journal of Comparative Sociology, 60(3), 117-139. https://doi.org/10.1177/0020715219845033

Littoz-Monnet, A. (2017). The politics of expertise in international organizations: How international bureaucracies produce and mobilize knowledge. Routledge.

Mead, G. H. (1962). Mind, self, and society. University of Chicago.

Meyer, J. W. (1996). Otherhood: The promulgation and transmission of ideas in the modern organizational environment. In B. Czarniawska and G. Sevón (Eds.), Translating organizational change (pp. 241-252). De Gruyter. 
Meyer, J. W. (2019). Reflections on rationalization, actors, and others. In H. Hwang, J. Colyvas, \& G. S. Drori (Eds.), Agents, actors, actorhood: Institutional perspectives on the nature of agency, action, and authority (Research in the sociology of organizations, volume 58) (pp. 275-285). Emerald Publishing Limited.

Meyer, J. W. (2000). Globalization: Sources, and effects on national states and societies. International Society, $15,235-250$.

Meyer, J. W., Boli, J., \& Thomas, G. (1987). Ontology and rationalization in the western cultural account. In G. M. Thomas et al. (Eds.) Institutional structure: Constituting state, society, and the individual (pp. 2-37). Sage.

Meyer, J. W., Boli, J., Thomas, G. M., \& Ramirez, F. O. (1997). World society and the nation-state. American Journal of Sociology, 103(1), 144-181. https://doi.org/10.1086/231174

Meyer, J. W., \& Jepperson, R. L. (2000). The 'actors' of modern society: The cultural construction of social agency. Sociological Theory, 18(1), 100-120. https://doi.org/10.1111/0735-2751.00090

Mitchell, R. B. (2002-2019) International environmental agreements database project (Version 2018.1). http:// iea.uoregon.edu/

Olzak, S. (2006). The global dynamics of racial and ethnic mobilization. Stanford University Press.

Petiteville, F. (2018). International organizations beyond depoliticized governance. Globalizations, 15(3), 301313. https://doi.org/10.1080/14747731.2017.1370850

Power, M. (2004). Counting, control and calculation: Reflections on measuring and management. Human Relations, 57(6), 765-783. https://doi.org/10.1177/0018726704044955

Rao, V., \& Woolcock, M. (2007). The disciplinary monopoly in development research at the World Bank. Global Governance: A Review of Multilateralism and International Organisations, 13(4), 479-484. https:// doi.org/10.1163/19426720-01304003

Ravallion, M., \& Wagstaff, A. (2012). The World Bank's publication record. The Review of International Organizations, 7(4), 343-368. https://doi.org/10.1007/s11558-011-9139-0

Ruggie, J. G. (1998). What makes the world hang together? Neo-utilitarianism and the social constructivist challenge. International Organization, 52(4), 855-885. https://doi.org/10.1162/002081898550770

Schaub, M., Henck, A., \& Baker, D. P. (2017). The globalized "whole Child": cultural understandings of children and childhood in multilateral aid development policy, 1946-2010. Comparative Education Review, 61 (2), 298-326. https://doi.org/10.1086/690811

Schofer, E., Lerch, J. C., \& Meyer, J. W. (2018, August 11-14). Illiberal reactions to the university in the 21st century [Paper presentation]. Annual meeting of the American Sociological Association, Philadelphia.

Shandra, J. M. (2007). The World polity and deforestation: A quantitative, cross-national analysis. International Journal of Comparative Sociology, 48(1), 5-27. https://doi.org/10.1177/0020715207072157

Tallberg, J., \& Zürn, M. (2019). The legitimacy and legitimation of international organizations. Introduction and Framework. Review of International Organizations, 14(4), 581-606. https://doi.org/10.1007/s11558018-9330-7

Union of International Organizations. (2017). Yearbook of international organizations. Munich: UIA and K. G. Saur Verlag.

Zapp, M. (2017a). The scientization of the world polity. International organizations and the production of scientific knowledge, 1950-2015. International Sociology, https://doi.org/10.1177/0268580917742003

Zapp, M. (2017b). The World Bank and education: Governing (through) knowledge. International Journal of Educational Development, 53, 1-11. https://doi.org/10.1016/j.ijedudev.2016.11.007

Zapp, M. (2020). The authority of science and the legitimacy of International Organisations: OECD, UNESCO and World Bank in global education governance. Compare: A Journal of Comparative and International Education, https://doi.org/10.1080/03057925.2019.1702503

Zapp, M., \& Ramirez, F. O. (2019). Beyond isomorphism and internationalisation. Towards a global higher education regime. Comparative Education, https://doi.org/10.1080/03050068.2019.1638103 


\section{Appendix 1. List of global reports and author organizations}

\begin{tabular}{|c|c|c|c|c|c|}
\hline Report & Sector & Agency & IO abbrev. & IO full name & IO type \\
\hline The State of Food and Agriculture & 1947 agriculture $\&$ food & principle & FAO & $\begin{array}{l}\text { Food and Agriculture Organization of the } \\
\text { United Nations }\end{array}$ & IGO \\
\hline Amnesty International Annual Report & $\begin{array}{l}1961 \text { democracy, law \& human } \\
\text { rights }\end{array}$ & principle & Al & Amnesty International & INGO \\
\hline Freedom in the World & $\begin{array}{l}1973 \text { democracy, law \& human } \\
\text { rights }\end{array}$ & principle & Freedom House & Freedom House & INGO \\
\hline World Development Report & $\begin{array}{l}1978 \text { human development \& } \\
\text { empowerment }\end{array}$ & principle & WB & World Bank & IGO \\
\hline The Global Competitiveness Report & $\begin{array}{l}1979 \text { macro-economic, finance, } \\
\text { trade }\end{array}$ & principle & WEF & World Economic Forum & $\begin{array}{l}\text { other } \\
10\end{array}$ \\
\hline $\begin{array}{l}\text { Piracy Report Global Integrated Shipping } \\
\text { Information System (GISIS) }\end{array}$ & $\begin{array}{l}1982 \text { security \& safety \& crime } \\
\text { prevention }\end{array}$ & principle & IMO & International Maritime Organization & IGO \\
\hline World Cities Report & $\begin{array}{l}1986 \text { human development \& } \\
\text { empowerment }\end{array}$ & $\begin{array}{l}\text { non-social } \\
\text { entity }\end{array}$ & UN-Habitat & United Nations Human Settlement Programme & IGO \\
\hline World Resources Report & 1986 energy \& resources & $\begin{array}{l}\text { non-social } \\
\text { entity }\end{array}$ & WRI & World Resources Institute & INGO \\
\hline Global Food Policy Report & 1986 agriculture $\&$ food & social entity & IFPRI & International Food Policy Research Institute & IRI \\
\hline $\begin{array}{l}\text { Report on The Nutrition Situation In The World } \\
\text { (The Global Nutrition Report) }\end{array}$ & 1987 health \& well-being & social entity & UNSCN & United Nations System Standing Committee on Nutrition & IGO \\
\hline Human Rights Watch World Report & $\begin{array}{l}1989 \text { democracy, law \& human } \\
\text { rights }\end{array}$ & principle & HRW & Human Rights Watch & INGO \\
\hline Human Development Report & $\begin{array}{l}1990 \text { human development \& } \\
\text { empowerment }\end{array}$ & social entity & UN & United Nations & IGO \\
\hline World Investment Report & $\begin{array}{l}1991 \text { macro-economic, finance, } \\
\text { trade }\end{array}$ & principle & UNCTAD & United Nations Conference on Trade and Development & IGO \\
\hline World Economic Outlook & $\begin{array}{l}1993 \text { macro-economic, finance, } \\
\text { trade }\end{array}$ & principle & IMF & International Monetary Fund & IGO \\
\hline World Disasters Report & 1993 humanitarian \& crisis & principle & Red Cross & Red Cross & INGO \\
\hline The State of World Fisheries and Aquaculture & $\begin{array}{l}1994 \text { environment, biodiversity \& } \\
\text { animal rights }\end{array}$ & $\begin{array}{l}\text { non-social } \\
\text { entity }\end{array}$ & $\mathrm{FAO}$ & Food and Agriculture Organization of the United Nations & IGO \\
\hline $\begin{array}{l}\text { Redbook of Endangered Languages and Atlas of } \\
\text { the World's Languages in Danger }\end{array}$ & 1994 culture & social entity & UNESCO & $\begin{array}{l}\text { The United Nations Educational, Scientific and Cultural } \\
\text { Organization }\end{array}$ & IGO \\
\hline State of The World's Forests & $\begin{array}{l}1995 \text { environment, biodiversity \& } \\
\text { animal rights }\end{array}$ & $\begin{array}{l}\text { non-social } \\
\text { entity }\end{array}$ & FAO & Food and Agriculture Organization of the United Nations & IGO \\
\hline World Health Report & 1995 health \& well-being & principle & WHO & World Health Organization & IGO \\
\hline Least Developed Countries Report & $\begin{array}{l}1995 \text { human development \& } \\
\text { empowerment }\end{array}$ & social entity & UNCTAD & United Nations Conference on Trade and Development & IGO \\
\hline $\begin{array}{l}\text { Report on the State of the World's Plant Genetic } \\
\text { Resources for Food and Agriculture }\end{array}$ & $\begin{array}{l}1996 \text { environment, biodiversity \& } \\
\text { animal rights }\end{array}$ & $\begin{array}{l}\text { non-social } \\
\text { entity }\end{array}$ & FAO & Food and Agriculture Organization of the United Nations & IGO \\
\hline
\end{tabular}


Continued.

\begin{tabular}{|c|c|c|c|c|c|}
\hline Report & Sector & Agency & IO abbrev. & IO full name & IO type \\
\hline World Wealth Report & $\begin{array}{l}1996 \text { macro-economic, finance, } \\
\text { trade }\end{array}$ & principle & Capgemini & Capgemini SE & $\begin{array}{l}\text { for- } \\
\text { profit }\end{array}$ \\
\hline Economic Freedom of the World & $\begin{array}{l}1996 \text { democracy, law \& human } \\
\text { rights }\end{array}$ & principle & Fraser Institute & Fraser Institute & IRI \\
\hline Global Report on Human Settlements & $\begin{array}{c}1996 \text { human development \& } \\
\text { empowerment }\end{array}$ & social entity & UN-Habitat & United Nations Human Settlement Programme & IGO \\
\hline The State of the World's Children & $\begin{array}{c}1996 \text { human development \& } \\
\text { empowerment }\end{array}$ & social entity & UNICEF & The United Nations Children's Fund & IGO \\
\hline Global Environment Outlook & $\begin{array}{l}1997 \text { environment, biodiversity \& } \\
\text { animal rights }\end{array}$ & $\begin{array}{l}\text { non-social } \\
\text { entity }\end{array}$ & UN & United Nations & IGO \\
\hline Report on The World Social Situation & $\begin{array}{l}1997 \text { human development \& } \\
\text { empowerment }\end{array}$ & social entity & UN DESA - DSPD & $\begin{array}{l}\text { United Nations Department of Economic and Social Affairs - } \\
\text { Social Policy and Development Division }\end{array}$ & IGO \\
\hline World Drug Report & 1997 health \& well-being & social entity & UNODC & United Nations Office on Drugs and Crime & IGO \\
\hline $\begin{array}{l}\text { Landmine Monitor and Cluster Munition Monitor } \\
\text { Report }\end{array}$ & $\begin{array}{l}1999 \text { security \& safety \& crime } \\
\text { prevention }\end{array}$ & principle & CMC & Landmine and Cluster Munition Monitor & INGO \\
\hline State of Food Insecurity in the World & 1999 agriculture \& food & social entity & FAO & Food and Agriculture Organization of the United Nations & IGO \\
\hline $\begin{array}{l}\text { Global Report on Freedom of Association and } \\
\text { Collective Bargaining }\end{array}$ & $\begin{array}{l}2000 \text { democracy, law \& human } \\
\text { rights }\end{array}$ & principle & ILO & International Labour Organization & IGO \\
\hline World Migration Report & $\begin{array}{l}2000 \text { migration, mobility \& } \\
\text { tourism }\end{array}$ & social entity & $\mathrm{IOM}$ & International Organization for Migration & IGO \\
\hline Nuclear Safety Global Review & $\begin{array}{l}2001 \text { security \& safety \& crime } \\
\text { prevention }\end{array}$ & principle & IAEA & The International Atomic Energy Agency & IGO \\
\hline The Global Information Technology Report 2016 & 2001 ICT & principle & WEF & World economic Forum & $\begin{array}{l}\text { other } \\
10\end{array}$ \\
\hline World Population Monitoring & $\begin{array}{c}2001 \text { human development \& } \\
\text { empowerment }\end{array}$ & social entity & UN DESA & United Nations Department of Economic and Social Affairs & IGO \\
\hline Industrial Development Report & $\begin{array}{l}2002 \text { macro-economic, finance, } \\
\text { trade }\end{array}$ & principle & UNIDO & United Nations Industrial Development Organization & IGO \\
\hline World Report on Violence and Health & 2002 health \& well-being & social entity & WHO & World Health Organization & IGO \\
\hline Education for All Global Monitoring Report & 2002 education \& science & social entity & UNESCO & $\begin{array}{l}\text { The United Nations Educational, Scientific and Cultural } \\
\text { Organization }\end{array}$ & IGO \\
\hline World Water Development Report & $\begin{array}{l}2003 \text { environment, biodiversity \& } \\
\text { animal rights }\end{array}$ & $\begin{array}{l}\text { non-social } \\
\text { entity }\end{array}$ & UN-Water & United Nations inter-Agency Coordination Mechanism & IGO \\
\hline Global Report on Equality at Work & 2003 work & principle & ILO & International Labour Organization & IGO \\
\hline World Report on Internal Displacement & $\begin{array}{l}2003 \text { migration, mobility \& } \\
\text { tourism }\end{array}$ & social entity & IDMC & Internal Displacement Monitoring Centre & INGO \\
\hline State of Agricultural Commodity Markets & $\begin{array}{l}2004 \text { macro-economic, finance, } \\
\text { trade }\end{array}$ & $\begin{array}{l}\text { non-social } \\
\text { entity }\end{array}$ & FAO & Food and Agriculture Organization of the United Nations & IGO \\
\hline The State of The World Population & $\begin{array}{c}2004 \text { human development \& } \\
\text { empowerment }\end{array}$ & social entity & UNFPA & United Nations Population Fund & IGO \\
\hline Report on the Global Aids Epidemic & 2004 health \& well-being & social entity & $\begin{array}{l}\text { WHO } \\
\text { UNAIDS }\end{array}$ & $\begin{array}{l}\text { World Health Organization } \\
\text { UNAIDS }\end{array}$ & IGO \\
\hline World Energy Outlook & 2005 energy \& resources & $\begin{array}{l}\text { non-social } \\
\text { entity }\end{array}$ & IEA & International Energy Agency & IGO \\
\hline
\end{tabular}

O

ther

GO

INO

GO 
Continued.

\begin{tabular}{|c|c|c|c|c|c|}
\hline Report & Sector & Agency & IO abbrev. & IO full name & IO type \\
\hline World Mortality Report & 2005 health \& well-being & principle & UN DESA & United Nations Department of Economic and Social Affairs & IGO \\
\hline Renewables Global Status Report & 2005 energy \& resources & principle & REN21 & Renewable Energy Policy Network for the twenty-first Century & $\begin{array}{l}\text { other } \\
10\end{array}$ \\
\hline World Population Ageing Report & $\begin{array}{c}2005 \text { human development \& } \\
\text { empowerment }\end{array}$ & social entity & UN DESA & United Nations Department of Economic and Social Affairs & IGO \\
\hline UNESCO Science Report & 2005 education \& science & social entity & UNESCO & $\begin{array}{l}\text { The United Nations Educational, Scientific and Cultural } \\
\text { Organization }\end{array}$ & IGO \\
\hline World Report on Regional Integration & 2006 political integration & principle & UNU-CRIS & $\begin{array}{l}\text { United Nations University Institute on Comparative Regional } \\
\text { Integration Studies }\end{array}$ & IRI \\
\hline Annual Report & $\begin{array}{l}2006 \text { macro-economic, finance, } \\
\text { trade }\end{array}$ & principle & IFC & International Finance Corporation & IGO \\
\hline Global Risks Report & 2006 humanitarian \& crisis & principle & WEF & World Economic Forum & $\begin{array}{l}\text { other } \\
10\end{array}$ \\
\hline World Report on Violence Against Children & $\begin{array}{l}2006 \text { human development \& } \\
\text { empowerment }\end{array}$ & social entity & UNICEF & The United Nations Children's Fund & IGO \\
\hline The Global Gender Gap Report & $\begin{array}{c}2006 \text { human development \& } \\
\text { empowerment }\end{array}$ & social entity & WEF & World Economic Forum & $\begin{array}{l}\text { other } \\
10\end{array}$ \\
\hline $\begin{array}{l}\text { State of the World's Animal Genetic Resources for } \\
\text { Food and Agriculture }\end{array}$ & $\begin{array}{l}2007 \text { environment, biodiversity \& } \\
\text { animal rights }\end{array}$ & $\begin{array}{l}\text { non-social } \\
\text { entity }\end{array}$ & $\mathrm{FAO}$ & Food and Agriculture Organization of the United Nations & IGO \\
\hline $\begin{array}{l}\text { Global Report on Conflict, Governance and State } \\
\text { Fragility }\end{array}$ & $\begin{array}{l}2007 \text { security \& safety \& crime } \\
\text { prevention }\end{array}$ & principle & CSP & Center for Systemic Peace & IRI \\
\hline Global Travel and Tourism Report & $\begin{array}{l}2007 \text { migration, mobility \& } \\
\text { tourism }\end{array}$ & social entity & WEF & World Economic Forum & $\begin{array}{l}\text { other } \\
10\end{array}$ \\
\hline $\begin{array}{l}\text { International Report on Crime Prevention and } \\
\text { Community Safety }\end{array}$ & $\begin{array}{l}2008 \text { security \& safety \& crime } \\
\text { prevention }\end{array}$ & principle & ICPC & International Centre for the Prevention of Crime & INGO \\
\hline Global Enabling Trade Report & $\begin{array}{l}2008 \text { macro-economic, finance, } \\
\text { trade }\end{array}$ & principle & WEF & World Economic Forum & $\begin{array}{l}\text { other } \\
10\end{array}$ \\
\hline Global Digital Report & $2008 \mathrm{ICT}$ & principle & We Are Social & We Are Social & $\begin{array}{l}\text { for- } \\
\text { profit }\end{array}$ \\
\hline Joint Global Report on Hygiene Matters & 2008 health \& well-being & principle & $\begin{array}{l}\text { WSSCC } \\
\text { SCA/Essity }\end{array}$ & $\begin{array}{l}\text { Water Supply and Sanitation Collaborative Council } \\
\text { SCA/ Essity }\end{array}$ & $\begin{array}{l}\text { IGO } \\
\text { for- } \\
\text { profit }\end{array}$ \\
\hline $\begin{array}{l}\text { Global Report on Local Democracy and } \\
\text { Decentralization }\end{array}$ & $\begin{array}{l}2008 \text { democracy, law \& human } \\
\text { rights }\end{array}$ & principle & GOLD & $\begin{array}{l}\text { Global Observatory on Local Democracy and } \\
\text { Decentralizationalization and Decentralization (GOLD) }\end{array}$ & INGO \\
\hline World of Work Report & $\begin{array}{c}2008 \text { human development \& } \\
\text { empowerment }\end{array}$ & social entity & ILO & International Labour Organization & IGO \\
\hline State of The World's Indigenous Peoples & $\begin{array}{c}2008 \text { human development \& } \\
\text { empowerment }\end{array}$ & social entity & UN DESA & United Nations Department of Economic and Social Affairs & IGO \\
\hline UNODC Report on Human Trafficking & $\begin{array}{l}2009 \text { security \& safety \& crime } \\
\text { prevention }\end{array}$ & social entity & UNODC & United Nations Office on Drugs and Crime & IGO \\
\hline Global Report on Adult Learning and Education & 2009 education \& science & social entity & UNESCO & $\begin{array}{l}\text { The United Nations Educational, Scientific and Cultural } \\
\text { Organization }\end{array}$ & IGO \\
\hline UNESCO World Report on Cultural Diversity & 2009 culture & social entity & UNESCO & $\begin{array}{l}\text { The United Nations Educational, Scientific and Cultural } \\
\text { Organization }\end{array}$ & IGO \\
\hline
\end{tabular}

\section{empowerment}

2006 political integration

principle UNU-CRIS

principle IFC

principle WEF

owerment empowerment

$$
\text { animal rights }
$$

$$
\text { prevention }
$$

principle ICPC macro-economic, finance, principle WEF

2008 ICT

principle We Are Social

WSSCC

SCA/Essity

rights

empowerment

security \& safety \& crime prevention

2009 culture 
Continued.

\begin{tabular}{|c|c|c|c|c|c|}
\hline Report & Sector & Agency & IO abbrev. & IO full name & IO type \\
\hline Global Biodiversity Outlook & $\begin{array}{l}2010 \text { environment, biodiversity \& } \\
\text { animal rights }\end{array}$ & $\begin{array}{l}\text { non-social } \\
\text { entity }\end{array}$ & CBD & Convention on Biological Diversity-UNEP & IGO \\
\hline World Social Science Report & 2010 education \& science & social entity & UNESCO & $\begin{array}{l}\text { The United Nations Educational, Scientific and Cultural } \\
\text { Organization }\end{array}$ & IGO \\
\hline $\begin{array}{l}\text { State of the World's Land and Water Resources for } \\
\text { Food and Agriculture }\end{array}$ & 2011 agriculture \& food & $\begin{array}{l}\text { non-social } \\
\text { entity }\end{array}$ & FAO & Food and Agriculture Organization of the United Nations & IGO \\
\hline WJP Rule of Law Index Report & $\begin{array}{l}2011 \text { democracy, law \& human } \\
\text { rights }\end{array}$ & principle & WJP & World Justice Project & INGO \\
\hline Progress of The World's Women & $\begin{array}{l}2011 \text { human development \& } \\
\text { empowerment }\end{array}$ & social entity & UN & United Nations & IGO \\
\hline UN World Youth Report & $\begin{array}{l}2011 \text { human development \& } \\
\text { empowerment }\end{array}$ & social entity & UN DESA & United Nations Department of Economic and Social Affairs & IGO \\
\hline \multirow[t]{2}{*}{ World Report on Disability } & $\begin{array}{l}2011 \text { human development \& } \\
\text { empowerment }\end{array}$ & social entity & WHO & World Health Organization & IGO \\
\hline & & & WB & World Bank & IGO \\
\hline Global Status Report on Road Safety & $\begin{array}{l}2012 \text { security \& safety \& crime } \\
\text { prevention }\end{array}$ & principle & WHO & World Health Organization & IGO \\
\hline $\begin{array}{l}\text { Annual Report on Human Rights and Democracy in } \\
\text { the World }\end{array}$ & $\begin{array}{l}2012 \text { democracy, law \& human } \\
\text { rights }\end{array}$ & principle & EU & European Union & IGO \\
\hline Global Report on Food Tourism & $\begin{array}{l}2012 \text { migration, mobility \& } \\
\text { tourism }\end{array}$ & social entity & UNWTO & World Tourism Organization & IGO \\
\hline Second Global Report on LGBT Tourism & $\begin{array}{l}2012 \text { migration, mobility \& } \\
\text { tourism }\end{array}$ & social entity & UNWTO & World Tourism Organization & IGO \\
\hline \multirow[t]{2}{*}{ Female Genital Mutilation Annual Report } & $\begin{array}{c}2012 \text { human development \& } \\
\text { empowerment }\end{array}$ & social entity & UNICEF & The United Nations Children's Fund & IGO \\
\hline & & & UNFPA & United Nations Population Fund & IGO \\
\hline Child And Youth Finance International Report & $\begin{array}{c}2012 \text { human development \& } \\
\text { empowerment }\end{array}$ & social entity & CYFI & Child And Youth Finance International & INGO \\
\hline World Happiness Report & 2012 health \& well-being & social entity & UN SDSN & UN Sustainable Development Solutions Network & $\begin{array}{l}\text { other } \\
10\end{array}$ \\
\hline Global Financial Development Report & $\begin{array}{l}2013 \text { macro-economic, finance, } \\
\text { trade }\end{array}$ & principle & WB & World Bank & IGO \\
\hline Human Capital Report & 2013 work & social entity & WEF & World Economic Forum & $\begin{array}{l}\text { other } \\
10\end{array}$ \\
\hline $\begin{array}{l}\text { Global Report on Industrial and Service } \\
\text { Cooperatives }\end{array}$ & 2013 work & social entity & CICOPA & $\begin{array}{l}\text { International Organisation of Industrial and Service } \\
\text { Cooperatives }\end{array}$ & INGO \\
\hline World Report on Child Labour & $\begin{array}{l}2013 \text { human development \& } \\
\text { empowerment }\end{array}$ & social entity & ILO & International Labour Organization & IGO \\
\hline Biennial Reports of the IWC & $\begin{array}{l}2014 \text { environment, biodiversity \& } \\
\text { animal rights }\end{array}$ & $\begin{array}{l}\text { non-social } \\
\text { entity }\end{array}$ & IWC & International Whaling Commission & IGO \\
\hline State of the World's Forest Genetic Resources & $\begin{array}{l}2014 \text { environment, biodiversity \& } \\
\text { animal rights }\end{array}$ & $\begin{array}{l}\text { non-social } \\
\text { entity }\end{array}$ & FAO & Food and Agriculture Organization of the United Nations & IGO \\
\hline Report on Global Internet Access & 2014 ICT & principle & $\mathrm{FB}$ & Facebook & $\begin{array}{l}\text { for- } \\
\text { profit }\end{array}$ \\
\hline
\end{tabular}




\begin{tabular}{|c|c|c|c|c|c|}
\hline Report & Sector & Agency & IO abbrev. & IO full name & IO type \\
\hline Global Internet Report & 2014 ICT & principle & ISOC & Internet Society & INGO \\
\hline World Social Protection Report & $\begin{array}{c}2014 \text { human development \& } \\
\text { empowerment }\end{array}$ & principle & ILO & International Labour Organization & IGO \\
\hline Global Sustainable Development Report & $\begin{array}{l}2014 \text { environment, biodiversity \& } \\
\text { animal rights }\end{array}$ & principle & UN & United Nations & IGO \\
\hline Academic Freedom Monitoring Report & $\begin{array}{l}2014 \text { democracy, law \& human } \\
\text { rights }\end{array}$ & principle & SAR & Scholars at Risk & INGO \\
\hline Global Media Report & 2014 ICT & social entity & McKinsey \& Co & McKinsey \& Company & $\begin{array}{l}\text { for- } \\
\text { profit }\end{array}$ \\
\hline Global Report on Antibiotic Resistance & 2014 health \& well-being & social entity & WHO & World Health Organization & IGO \\
\hline Status of the World's Soil Resources & 2015 energy \& resources & $\begin{array}{l}\text { non-social } \\
\text { entity }\end{array}$ & FAO & Food and Agriculture Organization of the United Nations & IGO \\
\hline Global Opportunity Report & $\begin{array}{c}2015 \text { human development \& } \\
\text { empowerment }\end{array}$ & principle & UN & United Nations & IGO \\
\hline International Migration Report & $\begin{array}{l}2015 \text { migration, mobility \& } \\
\text { tourism }\end{array}$ & social entity & UN & United Nations & IGO \\
\hline The Inclusive Growth Report & $\begin{array}{c}2015 \text { human development \& } \\
\text { empowerment }\end{array}$ & social entity & WEF & World Economic Forum & $\begin{array}{l}\text { other } \\
10\end{array}$ \\
\hline Global Widows Report & $\begin{array}{c}2015 \text { human development \& } \\
\text { empowerment }\end{array}$ & social entity & $\begin{array}{l}\text { The Loomba } \\
\text { Foundation }\end{array}$ & The Loomba Foundation & INGO \\
\hline Report on The State of the World's Plants & $\begin{array}{l}2016 \text { environment, biodiversity \& } \\
\text { animal rights }\end{array}$ & $\begin{array}{l}\text { non-social } \\
\text { entity }\end{array}$ & FAO & Food and Agriculture Organization of the United Nations & IGO \\
\hline Global Financial Stability Report & $\begin{array}{l}2016 \text { macro-economic, finance, } \\
\text { trade }\end{array}$ & principle & IMF & International Monetary Fund & IGO \\
\hline Rural Development Report & $\begin{array}{c}2016 \text { human development \& } \\
\text { empowerment }\end{array}$ & principle & IFAD & International Fund For Agricultural Development & IGO \\
\hline World Employment and Social Outlook & $\begin{array}{c}2016 \text { human development \& } \\
\text { empowerment }\end{array}$ & principle & ILO & International Labour Organization & IGO \\
\hline World Diabetes Report & 2016 health \& well-being & social entity & WHO & World Health Organization & IGO \\
\hline Global Report on Food Crises & 2017 humanitarian \& crisis & social entity & WFP & World Food Program & IGO \\
\hline \multirow[t]{2}{*}{ Global Report on Inclusive Tourism Destinations } & $\begin{array}{l}2018 \text { migration, mobility \& } \\
\text { tourism }\end{array}$ & social entity & UNWTO & World Tourism Organization & IGO \\
\hline & & & & Globaldit & $\begin{array}{l}\text { for- } \\
\text { profit }\end{array}$ \\
\hline Global Report on Deafblindness & $\begin{array}{c}2018 \text { human development \& } \\
\text { empowerment }\end{array}$ & social entity & WFDB & World Federation of the Deafblind & INGO \\
\hline $\begin{array}{l}\text { State of the World's Biodiversity for Food and } \\
\text { Agriculture }\end{array}$ & $\begin{array}{l}2019 \text { environment, biodiversity \& } \\
\text { animal rights }\end{array}$ & $\begin{array}{l}\text { non-social } \\
\text { entity }\end{array}$ & FAO & Food and Agriculture Organization of the United Nations & IGO \\
\hline $\begin{array}{l}\text { Global Assessment Report on Biodiversity and } \\
\text { Ecosystem Services }\end{array}$ & $\begin{array}{l}2019 \text { environment, biodiversity \& } \\
\text { animal rights }\end{array}$ & $\begin{array}{l}\text { non-social } \\
\text { entity }\end{array}$ & IPBES & $\begin{array}{l}\text { Intergovernmental Science-Policy Platform on Biodiversity and } \\
\text { Ecosystem Services }\end{array}$ & IGO \\
\hline Global Report on Environmental Rule of Law & $\begin{array}{l}2019 \text { democracy, law \& human } \\
\text { rights }\end{array}$ & principle & UN & United Nations & IGO \\
\hline
\end{tabular}

Global Sustainable Development Report

Global Report on Antibiotic Resistance

Status of the World's Soil Resources

International Migration Report

Global Widows Report

Rural Development Report

World Employment and Social Outlook

Global Report on Food Crises

umanitarian \& crisis

social entity WHO

social entity WFP tourism 


\section{Appendix 2. Coding system for agency types (principles and entities)}

\begin{tabular}{|c|c|c|c|}
\hline Category & Concepts & in-vivo codes & report examples \\
\hline principle & $\begin{array}{l}\text { abstract, values, rules, non-personal, institutional, } \\
\text { non-tangible, cultural, rights, goals }\end{array}$ & $\begin{array}{l}\text { human rights, equality, } \\
\text { security, peace }\end{array}$ & $\begin{array}{l}\text { Scholar at Risk's Academic } \\
\text { Freedom Monitoring Report }\end{array}$ \\
\hline $\begin{array}{l}\text { non-social non- } \\
\text { actor entities }\end{array}$ & $\begin{array}{l}\text { physical, natural, animals, built, external to } \\
\text { humans }\end{array}$ & $\begin{array}{l}\text { animals, plants, cities, } \\
\text { water }\end{array}$ & UNEP's Global Biodiversity Outlook \\
\hline $\begin{array}{l}\text { social non-actor } \\
\text { entities }\end{array}$ & $\begin{array}{l}\text { human, social, living, groups, milieu, aggregated } \\
\text { individuals, persons, professions, roles }\end{array}$ & $\begin{array}{l}\text { migrants, elderly, } \\
\text { scientists, LGTBQ }\end{array}$ & $\begin{array}{l}\text { Loomba Foundation's Global } \\
\text { Widows Report }\end{array}$ \\
\hline
\end{tabular}

Appendix 3. Coding system for levels of aggregation

\begin{tabular}{llc}
\hline Category & \multicolumn{1}{c}{ Concepts } & in-vivo codes/ examples \\
\hline $\begin{array}{c}\text { inter-state/ inter- } \\
\text { national } \\
\text { groups/regional/ } \\
\text { area }\end{array}$ & $\begin{array}{c}\text { statist, state-centric, national } \\
\text { aggregated country groups, geographically-/ } \\
\text { culturally-/ economically defined } \\
\text { worldwide, earth, planet, unitary, holistic, all- } \\
\text { encompassing }\end{array}$ & $\begin{array}{c}\text { total number of children below poverty line in the European } \\
\text { Union; people in absolute poverty in the Middle East } \\
\text { total number of widows worldwide; global gross domestic } \\
\text { product }\end{array}$ \\
\hline
\end{tabular}

